\title{
The Failure of Dialogue: WINNIPEG CHILD AND FAMILY SERVICES (NORTHWEST AREA) V. G. (D.F.)
}

\author{
BRUCE P. Elman AND JILl MaSON
}

\section{INTRODUCTION}

The facts of this case present us with a tragic, but all too familiar, story. ${ }^{\prime}$ As proceedings began, Ms. G., a twenty-two year old Aboriginal woman, was pregnant with her fourth child. She suffered from a chronic and severe glue-sniffing addiction. Winnipeg Child and Family Services (Northwest Area) (hereinafter referred to as WCFS), had obtained permanent orders of guardianship for Ms. G.'s first three children before they reached two years of age. Two of the children were born with addictions to chemicals and all three were developmentally delayed as a result of Ms. G.'s chemical dependency during her pregnancies.

The background to this case reveals the harmful effects of chronic and severe substance abuse, not only on the unborn child, but on Ms. G. as well. In 1990, Ms G., then sixteen years old and pregnant, was deemed to be a "child in need of protection" and was, consequently, placed in a residential youth treatment facility. At that time, she was pregnant with her first child and, even then, had adopted an unstable lifestyle including the abuse of solvents. She was subsequently placed in a residential facility designed to assist young mothers with the care of their infants. At that time, Ms. G. was unable to alter her lifestyle and she continued to suffer from addiction. When visited by social workers, a strong odour of glue pervaded her apartment and Ms. G. displayed the classic signs of impairment. She began to prostitute to support her addiction and, on several occasions, she attempted to take her own life.

In May 1996, Ms. G. entered the hospital complaining of difficulty walking, loss of balance, weakness, and nausea - all symptoms of chronic and severe solvent abuse. Ms. G. was admitted to the Chemical Withdrawal Unit. Her diagnosis was: "solvent abuse with cerebellar disease and probable cognitive impairment." ${ }^{2}$ Ms. G. was discharged from the hospital on June 6 but was readmitted on June 27. She was suffering a loss of co-ordination brought on by glue sniffing. After this episode, the hospital informed WCFS that Ms. G. was pregnant and that the baby was due in December.

Bruce P. Elman, Belzberg Professor of Constitutional Law and Chair, Centre for Constitutional Studies, Faculty of Law, University of Alberta, Edmonton, Canada; Jill Mason, LL.M. (Candidate), Faculty of Law, University of Alberta, Edmonton, Canada.

1 The facts recited here are an amalgam of those recounted in the three levels of court through which the case proceeded: Winnipeg Child and Family Services (Northwest Area) v. G. (D.F.) (1997), 152 D.L.R. (4th) 193 (S.C.C.), affg (1996), 138 D.L.R. (4th) 254 (Man. C.A.), rev'g (1996), 138 D.L.R. (4th) 238 (Man. Q.B.) [hereinafter D.F.G.]. 
A social worker visited Ms. G. at her home on July 18. At that time, Ms. G. agreed to voluntarily enter a residential treatment program for substance abuse. However, when the social worker returned on July 23 to transport Ms. G. to the treatment facility, the social worker found Ms. G. in an intoxicated state, smelling of solvents. Ms. G. refused to enter the treatment program at that time. Consequently, on August 1, WCFS brought a motion before Justice Schulman of the Manitoba Court of Queen's Bench for an order compelling Ms. G. to reside at a place of safety and to refrain from further consumption of drugs or other intoxicating substances until the birth of the child. Justice Schulman found that Ms. G.'s mental state engaged the "jurisdiction of this Court under the Mental Health Act"3 and provided "a strong prima facie foundation for the exercise of the court's parens patriae powers." 4 Based upon these findings, Justice Schulman ordered that Ms. G. be remanded into the custody of WCFS who was given authority to arrange for her treatment. WCFS was also given authority to apply, without notice, for an order committing Ms. G. for treatment if she failed to complete the course of treatment prescribed by WCFS.

Ms. G. entered the hospital on August 6. A stay was ordered by Justice Helper of the Manitoba Court of Appeal on August $8 .^{5}$ Nonetheless, Ms. G. chose to voluntarily continue treatment and she remained in the hospital until discharged by her physician on August 14. WCFS provided Ms. G. with a teaching homemaker and a public health nurse who visited regularly. The Manitoba Court of Appeal vacated Justice Schulman's order on September 12. Justice Twaddle, writing on behalf of a unanimous Court, held that Justice Schulman's conclusion that Ms. G. was "mentally disordered" pursuant to the provisions of the Mental Health Act $^{6}$ was not supported by the evidence. Nor, according to the Appeal Court Justice, did the evidence support a finding of incompetence as required for the exercise of the court's parens patriae jurisdiction.

The story seems to have a happy ending: On 6 December 1996, Ms. G. delivered an apparently healthy baby boy, she continued to receive twenty-four hour in-home support and as of the Supreme Court of Canada hearing, Ms. G. remained drug-free.

The legal conclusion is not as joyous. WCFS appealed to the Supreme Court of Canada. On 31 October 1997, the Court dismissed the appeal. Justice McLachlin, writing on behalf of the majority, stated that “... an order detaining a pregnant woman for the purpose of protecting her fetus would require changes to the law which cannot be properly made by the courts and should be left to the legislature."

For the most part, the majority judgment addresses whether tort law may be extended to permit an order detaining a pregnant woman in order to protect her unborn child. The majority rejects this idea. Secondly, the majority considers whether the court's

G.S.M. 1987, c. M-110.

T D.F.G., supra note 1 at 199 (S.C.C.).

Ibid. at 252.

Ibid. at 253 . (QL).

"Manitoba Looks for Options to Protect Fetal Rights" Canadian Press NEWSTEX (9 August 1996) 
parens patriae jurisdiction can be extended to permit such an order and concludes that it cannot.

Justices Major and Sopinka, in dissent, concluded that in situations where the mother decides to carry the child to term, it would be appropriate, in narrowly defined circumstances, to extend the Court's parens patriae jurisdiction to protect the unborn child from substance abuse during pregnancy. Although it may have been preferable for the legislature to act, "its failure to do so is not an excuse for the judiciary to follow the same course of inaction."

The minority examined the breadth of the parens patriae jurisdiction at length ${ }^{9}$ as described by the Supreme Court of Canada in E. (Mrs.) v. Eve. ${ }^{10}$ The basis for the jurisdiction, exercised most frequently in regard to children, "exists for the stated purpose of doing what is necessary to protect the interests of those who are unable to protect themselves." scope. $^{12}$ It is available to address unforeseen situations even when legislation exists in the area. The jurisdiction can be used to protect the vulnerable from anticipated injury. One cannot precisely define the limits of the parens patriae power because each case depends on its own facts. The parens patriae jurisdiction has inexorably "moved towards a broader discretion, under the impact of changing social conditions and the weight of opinion..." 13 The minority concluded that while the breadth of the parens patriae jurisdiction is apparent from the Supreme Court of Canada decision in Re Eve, "... what is unclear is whether the jurisdiction to act in the best interests of a child can also include the power to act in the best interests of a foetus." ${ }^{\prime 4}$ In concluding that the parens patriae should be extended to protect the unborn child, the minority declared:

If a foetus is a "person" for the purposes of the parens patriae, he or she is in a particularly vulnerable position. A foetus, absent outside assistance, has no means of escape from toxins ingested by its mother. The parens patriae jurisdiction exists for the stated purpose of doing what is necessary to protect the interests of those who are unable to protect themselves. Society does not simply sit by and allow a mother to abuse her child after birth. How then should serious abuse be allowed to occur before the child is born? ${ }^{15}$

Ibid. at 242.

lbid. at 229-31.

[1986] 2 S.C.R. 388 [hereinafter Re. Eve].

D.F.G., supra note 1 at 232 (S.C.C.).

Ibid. at 229-30. In reviewing Justice La Forest's examination of the history and scope of the parens patriae jurisdiction, the minority concluded that his reasons explain the "undefined and indefinable breadth of the power of the court in this area." Justice La Forest commented that in $\operatorname{Re} X$ (a minor), [1975] 1 All E.R. 697 (C.A.), Lord Denning declared that "[n]o limit has ever been set to the jurisdiction. It has been said to extend 'as far as necessary for protection and education'... The court has power to protect the ward from any interference with his or her welfare, direct or indirect" (ibid. at 230).

13 D.F.G., ibid. at 231. The minority cited Re Eve, supra note 10 at $425-27$ where Justice La Forest adopted the view of Lord MacDermott in J. v. C., [1970] A.C. 668 at 703.

is Ibid. at 231.

is $\quad$ lbid. at 232. 
On the contrary, based on legal precedent, ${ }^{16}$ the majority concluded that the parens patriae should not be extended. What a shame!

This comment will focus upon the deficiencies in the majority's judgment, highlight the positive elements in the dissent's analysis, and make some general observations on the need, as a last resort, to permit judicial intervention in pregnancy for the purpose of ordering mandatory treatment of the pregnant woman to protect the yet-to-be born ${ }^{17}$ child from the harmful effects of prenatal substance abuse.

\section{ANAlysis}

\section{A. "The FaCtS, MA'AM. All The FaCtS"}

On Dragnet, an early "cops and robbers" television program, Jack Webb would, at least once per episode, demand that witnesses tell him "the facts, ma'am, just the facts." Webb did not want to hear opinions that were irrelevant to the case. He did, however, require all the facts. Justice McLachlin begins her judgment by noting that the "outcome of the case" was "resolved" and, consequently, there was "little point in minutely canvassing the facts and allegations." 18 After this statement, a skeletal oneparagraph outline of the facts is provided.

The Court, frequently, will give only the barest delineation of the facts of a particular case when the Court's decision is based upon a principle of law requiring little, if any, factual background. Often these cases are being sent back to the lower courts for retrial. In such cases, it is important that the Supreme Court does not usurp the jurisdiction of any "future" trial court by giving a detailed description of the facts.

However, this was not the situation in the D.F.G. case. No retrial was in the offering. Although one might argue that the majority's decision was based upon a principle of law that did not require an extensive factual underpinning, what was fundamentally at stake was whether there exists a situation - previously undiagnosed - which requires an expansion of the Court's discretionary power to protect children from harm when they are in danger. To be less obtuse: knowing the long-term and irreparable damage that a pregnant woman's substance abuse will cause her fetus and given the irrefutable evidence of the destruction which substance abuse had, in fact, caused Ms. G. and her

Ibid. at 215-18. It is implicit in the minority decision that it disapproved of this approach, in part, on the basis that "[r]igidly applying precedents of questionable applicability without inquiry will lead the law to recommit errors of the past" (ibid. at 237-38). i.e. where aborting the fetus is not contemplated. We are admittedly inconsistent in this and sometimes use the term interchangeably with the term "unborn." examined the facts admitted at trial, as well as additional facts concerning the case (Ibid. at 22024). Furthermore, the minority examined additional facts admitted by several interveners concerning "the prevalence of mental and physical disabilities in children as result of substance abuse by their mother while pregnant. Some of this evidence also focused on the 'crisis situation' in many aboriginal communities" (ibid. at 224). See infra at 744 et seq. 
offspring, the majority should have explored the facts as extensively as possible, to determine whether an expansion of the parens patriae power to include yet-to-be born children was required. It should be noted that the parens patriae power was created by the Court and any limitations on the power are, also, the Court's own creation. An adjustment to those limitations could, logically, also be a creation of the Court.

A full and detailed examination of the facts - both adjudicative and legislative indicates an extremely serious situation, both for Ms. G. and her children as well as for children generally, which cries out for judicial action to prevent future harm to yet-tobe born children who are in danger. What facts are left out of Justice McLachlin's decision?

\section{THE AduUdicative Facts}

The adjudicative facts are those relevant to the specific litigation before the Court. They are the "who," "what," "where," "why," and "how" of the case. The evidence presented at trial focused on the serious detrimental effects of chronic and severe substance abuse from a multidisciplinary perspective. Substance addiction was extremely harmful to Ms. G.'s physical and mental health as well her social well-being. The evidence presented at trial further illustrated the harmful effects of substance abuse during pregnancy on Ms. G.'s children. ${ }^{19}$

Ms. G.'s two sisters testified that the family was very concerned about Ms. G.'s substance addiction. They noted that often when Ms. G. visited, she was "sniffed up," dazed, and smelling of solvents. On occasion, she could "hardly walk or talk." They had tried to convince Ms. G. to enter a treatment program but to no avail. ${ }^{20}$

Evidence of family members was confirmed by the social worker employed by the Social Services Department of the City of Winnipeg. Her testimony, based upon her involvement with Ms. G. since 1992, indicated that Ms. G. was a chronic abuser of solvents. Ms. G. had turned to prostitution as a way to finance her addiction. According to this witness, Ms G. had "consistently refused all offers of services or treatment." 21

The Director of Child Protection at the Health Sciences Centre testified based upon the hospital records relating to the births of Ms. G.'s second and third child. During confinement there was a noticeable odour of solvents indicating that Ms. G. was a solvent abuser. Further, the records disclosed that the children were developmentally delayed with a broad range of disabilities. ${ }^{22}$

Two psychiatrists also gave evidence based upon their examinations of Ms. G. which were undergone to determine whether commitment under the Mental Health Act was

\footnotetext{
1) The evidence that follows is excerpted from the decision of Justice Schulman (Manitoba Court of Queen's Bench). D.F.G., supra note 1 at 240-45 (Man. Q.B.).

Ibid. at 241.

Ibid. at 243.

Ibid. at 242.
} 
warranted. They noted that Ms. G. had a long and severe history of solvent abuse. She had engaged in acts of self-mutilation and had attempted suicide on numerous occasions. Indeed, it was their opinion that Ms. G. remained a long-term high risk for suicide. Further, they noted that she suffered from cerebellar degeneration. The psychiatrists concluded that Ms. G. suffered from "chronic solvent and mixed personality disorder, with anti-social and dependant features."23

Justice Schulman summarized the evidence concerning Ms. G.'s condition as follows:

That evidence establishes that she consistently tried to end her life, by hanging; has engaged in self mutilation; and has stopped eating for days on end, with no apparent reason for doing so. In addition, the evidence is that, if she continues to sniff glue and refuse treatment, she will in the short term, cause herself much more serious physical and mental harm, and before long, death. ${ }^{24}$

Experts were called to testify about the physical and psychological effects of substance abuse. The Medical Director of the Chemical Withdrawal Unit at the Health Sciences Centre testified that the acute effects of glue sniffing include nausea, vomiting, tremors, blurred vision, joint pain, chest pain, decreased level of consciousness, and seizures which can progress to coma or respiratory or cardiac arrest, leading to death. Kidney, liver and bone marrow failure can result from chronic use. The most serious organ damage occurred in the brain and could cause a decrease in intellectual capacity. The cerebellum which controls motor co-ordination could be damaged leading to a loss of sensation and generalized muscle weakness. ${ }^{25}$

The Head of the Section of Genetics and Metabolism testified concerning the effects on an unborn child whose mother "chronically abuses alcohol or chronically sniffs glue while pregnant." ${ }^{26} \mathrm{He}$ noted that these children, when born, exhibit "central nervous system dysfunction, developmental delay, attention deficit disorder, microcephaly, growth deficiency, short palpebral fissures, deep-set eyes, microagnathia, abnormal auricles and small fingernails." 27 Unborn children are particularly vulnerable in the first trimester. It was also noted, however, that "the damage done to the unborn infant can be reduced if exposure to glue is eliminated during the second and third trimesters. "28

Evidence provided by the Co-ordinator of an alcohol and abuse treatment centre indicated that they were willing to take Ms. G. on a residential basis. The program had

Ibid. at 245 [emphasis in original]. In the psychiatrists' opinions, there was no evidence of the need for an acute psychiatric intervention at the time. Nor did they believe that they had grounds to detain Ms. G. under the Mental Health Act. Justice Schulman disagreed with their opinions and supported her commitment under the Mental Health Act. The Court of Appeal disagreed and, inter alia, overturned on this point.

Ibid. at 246.

Ibid. at $241-42$.

Ibid. at 242.

Ibid.

Ibid. at 242 [emphasis added]. 
"some aboriginal staff and a strong cultural content for aboriginal persons." 29 Residents generally stayed between three months and six months, but a stay of a year or longer was recommended for individuals who suffered from long-term, chronic substance addiction. ${ }^{30}$

The picture which the evidence paints of Ms. G. and her family is a tragic one. Ms. G. suffered from the "ravages of addiction." ${ }^{31}$ She was physically, psychologically, and socially disintegrating. Her addiction not only destroyed her life and, most probably, the lives of her children, but threatened to do irreparable damage to the yetto-be born child. Furthermore, Ms. G. clearly demonstrated that she could not resolve her addiction problem on her own. Yet, the evidence indicated that she could gain access to a residential treatment program that was not punitive, but rather highly supportive and directed towards Ms. G.'s recovery. All of this evidence is uncontroverted.

Thus, based upon the indisputable adjudicative facts, Ms. G.'s case is a compelling one for extending the court's parens patriae jurisdiction to include the yet-to-be born child in order to promote the objective of "doing what is necessary to protect the interests of those who are unable to protect themselves." 32

\section{THE LEGISLATIVE FACTS}

Paciocco and Stuesser define legislative facts as those that "have relevance to legal reasoning and the law-making process and involve broad considerations of policy." Davis describes the category of legislative facts as follows:

When a court or agency develops law or policy, it is acting legislatively; the courts have created the common law through judicial legislation, and the facts which inform the tribunal's legislative judgement are called legislative facts. ${ }^{34}$

This is precisely what the Court in D.F.G. is being asked to do: extend a rule of common law, the limitation on which was previously justifiable, but which is no longer consonant with the legislative facts used to support it. New legislative facts concerning "general social context or social framework" 35 have arisen which require an extension

Ibid. at 241 .

Ibid.

D.F.G., supra note 1 at 200 (S.C.C.).

Ibid. at 232.

D. Paciocco \& L. Stuesser, The Law of Evidence (Concord, Ontario: Inwin Law, 1996) at 245. The distinction between adjudicative facts and legislative facts was articulated in K.C. Davis, "An Approach to Problems of Evidence in the Administrative Process" (1942) 55 Harv. L. Rev. 364.

K.C. Davis, "Judicial Notice" (1955) 55 Col. L. Rev. 945 at 948-49 [emphasis added]. Sce also R.J. Delisle, Evidence: Principles and Problems, 2d ed. (Toronto: Carswell, 1989) at 189-91. 
of the common law parens patriae power to include the yet-to-be-born child. These legislative facts are cited by the dissent. ${ }^{36}$ They include the following:

1. There is clear and convincing evidence that substance abuse (alcohol, gasoline, solvents and so forth) can lead to fetal alcohol syndrome (FAS) or fetal alcohol effects (FAE). FAS/FAE children suffer from development and cognitive impairment. They suffer from learning disabilities, attention deficit disorders, hyperactivity, and they have difficulty with ordinary relationships. ${ }^{37}$

2. Fetal Alcohol Syndrome is the "leading preventable cause of mental disability in the western world." 38

3. In addition to the direct health implications that substance abuse has for the physical and mental well being of the fetus (not to mention the addicted mother herself), there are many secondary disabilities associated with children who are born suffering FAS/FAE as a result of their mother's abuse. ${ }^{39}$ There is a clear inter-generational component to the syndrome and its associated disabilities. The tragic effects of FAS/FAE are borne by the society as a whole even beyond the present generation.

4. The tragedy of FAS/FAE is acutely felt in Aboriginal communities where the rates of incidence are considerably higher than in the general community and the effect is the most severe on members of that community. The Royal Commission on Aboriginal Peoples noted: "We believe that adults (who were born) with FAS/FAE are either on the street or in jail." ${ }^{40}$ Intervenors representing aboriginal communities urged the Court to expand the common law parens patriae to include yet-to-born children. ${ }^{41}$

D.F.G., supra note 1 at 224-27 (S.C.C.).

See Moffat et al., in Fetal Alcohol Syndrome. Fetal Alcohol Effects and the Impact of Alcohol Exposure during Pregnancy on School Performance and Behaviour in School-Age Children in a First Nations Community (November 1996) at 4.

Manitoba Children and Youth Secretariat, Strategy Considerations for Developing Services for Children and Youth (March 1997) at 15.

A. Streissguth et al., Understanding the Occurrence of Secondary Disabilities in Clients with Fetal Alcohol Syndrome (FAS) and Fetal Alcohol Effects (FAE) (August 1996).

Royal Commission on Aboriginal Peoples, Gathering Strength, vol. 3 (Ottawa: The Commission, 1996) at 132-33.

D.F.G., supra note I at 227 (S.C.C.). In so doing, they declared that "such a remedy was consistent with the aboriginal world view...." 
Once again, the conclusion is inescapable and indisputable: ${ }^{42}$ there is a crisis situation which is being felt particularly, but not exclusively, in our Aboriginal communities. Children are forced to lead a second-class life because they suffer injuries which are inflicted upon them when they are most vulnerable and least able to protect themselves - in the womb.

Therefore, on the basis of the overwhelming weight of the legislative facts, there is ample support for an extension of the protective power of parens patriae to include yetto-be-born children who are vulnerable to the ravages of substance abuse.

If the adjudicative facts of this case cry out for judicial intervention to right the wrong that is being perpetrated on the unborn child and the legislative facts support such an intervention, why is the majority so reluctant to extend the parens patriae jurisdiction to protect the unborn child? The answer, seemingly, is the dreaded "slippery slope."

\section{B. THE DREADEd "SlIPPERY SLOPE"}

The majority is obviously concerned with the possible unforeseen ramifications of extending the parens patriae jurisdiction to unborn children. Indeed they are obsessed with the issue. The minority is not. One can see this divergence of perspective in the articulation by each faction of the issue to be decided in the case. According to the majority:

... the legal question remains: assuming that a mother is acting in a way which may harm her unborn child, does a judge, at the behest of the state, have the power to order the mother to be taken into custody for the purpose of rectifying her conduct $?^{43}$

The question, so stated, implies that we are talking about any conduct, no matter how commonplace or innocuous, which may harm the unborn child. The minority perceives the question in a radically different way, focusing on whether or not:

It should be noted that the majority report of the Royal Commission on Reproductive Technologies, Proceed with Care: Final Report of the Royal Commission on New Reproductive Technologies, vol. 3 (Ottawa: Minister of Supply and Services Canada, 1993) [hereinafter Report] argued against any form of judicial interference in pregnancy. The Report did not dispute the seriousness of the problems associated with FAS/FAE but rather based its opposition to judicial interference on "the basic components of women's fundamental human rights - the right to bodily integrity, and the right to equality, privacy, and dignity" (at 958). The Report includes a strong dissent on this point. The Commission's work has been the subject of much criticism. See for example, P. Healy, "Statutory Prohibitions and the Regulation of New Reproductive Technologies under Federal Law in Canada" (1995) 40 McGill L.J. 905 at 911 . At footnote 2 Healy refers to another critical discussion of the Commission; see M. Eichler, "Frankenstein Meets Kafka: The Royal Commission on New Reproductive Technologies" in G. Bassen, M. Eichler \& A. Lippman, eds., Misconceptions: The Social Construction of Choice and the New Reproductive and Genetic Technologies, vol. 1 (Hull, Que.: Voyageur, 1993) at 196. 
... an order detaining a pregnant woman addicted to glue sniffing for which she has rejected abortion and/or medical treatment and decided to carry her child to term, would require a change to the law which cannot be properly made other than by legislation. ${ }^{4}$

This is an entirely different matter. The dissent has limited their judgment to instances of chronic substance abuse. We are well aware of the potential devastating effects of such abuse on the unborn child. The woman has rejected abortion and decided to carry the child to term. The risks, then, are potential but real. She has rejected medical treatment. Thus she cannot, perhaps because of the effect of substance abuse on her own cognitive powers, make a rational decision to seek help for her addiction. This does not give rise to the spectre of courts intervening anytime someone thinks that a woman's conduct is detrimental to her unborn child, that is, it does not conjure up images of the "slippery slope."

The majority's reliance on the "slippery slope" argument can be traced through many of the issues discussed by the Court. For example, in justifying its continued adherence to the "born alive" rule, the majority noted that if they departed from the rule, "the courts would find it difficult to limit the application of the new principle to particular cases." ${ }^{145}$ Further, on whether the Court should recognize a cause of action for lifestyle choices of pregnant women that adversely affect their unborn children, the majority expressed, somewhat hyperbolically, concern about how to limit the potential causes of action:

Are children to be permitted to sue their parents for second-hand smoke inhaled around the family dinner table?... Are children to be permitted to sue their parents for spanking causing psychological trauma or poor grades due to alcoholism or a parent's undue fondness for the office or the golf course? If we permit lifestyle actions, where do we draw the line? ? $^{46}$

The "slippery slope" should be of concern to the Court, however, it must be carefully assessed so as not to become "a in terrorem argument and lose whatever value it may legitimately possess." ${ }^{\$ 77}$ The "slippery slope" is present whenever we talk about rights. For example, when the Court discussed whether the hate propaganda provisions of the Criminal Code $e^{48}$ violated the guarantee of freedom of expression, the dissent raised the "slippery slope." ${ }^{49}$ In most instances in which there is an issue of limiting rights, the "slippery slope" rears its ugly head. In some of these instances, it is reasonable to be

Ibid. at 219 [emphasis added].

4s Jbid. at 206. The minority's response to the slippery slope argument was compelling. Justice Major declared:

Simply because there may be hard cases on other facts not before the Court does not mean we should ignore what is obvious from the evidence in this case. The damage caused to children by serious substance abuse is well documented. It seems derelict to suggest that we should not restrain this abuse because we can imagine some other cases that may not be as clear (ibid. at 238-39).

47 lbid. at 240.

48 R.S.C. 1985 , c. C-5.

49 R. v. Keegstra, [1991] 3 S.C.R. 697 at $859-60$ (per McLachlin J.). 
concerned about the issue; in others, it is not. Canadians, in our view, do not, collectively or personally, adhere to absolutist positions on social issues. We are, as reflected in our Charter, essentially balancers. We will accept some limitation on rights if the right is outweighed by other important social interests. Balancing was what the minority in D.F.G. tried to do.

The minority would approve an extension of the parens patriae jurisdiction but only for "extreme cases" ${ }^{50}$ where "no other reasonable means of treatment exists"sl and "no other solution is workable or effective." "abusive," the result of recklessness or addiction, and have the potential to inflict "serious and permanent damage onto a child she has decided to bring into the world." 53 The "remedy of confinement must be for the purposes of treatment and not punishment" ${ }^{54}$ and should be carried out at "a residential treatment facility or hospital which can offer a treatment program." ss The civil standard is appropriate but the threshold for state intervention is high. ${ }^{56}$ The Court must be "certain on a balance of probabilities that no other solution is workable or effective." 57 In short, according to the dissent, "the least rights-diminishing option should always be sought." 58 This, it seems to us, strikes a nice balance between the reproductive and bodily autonomy of the woman on the one hand and the state's interest in preventing harm to her yet-to-beborn child as a result of her substance addiction.

One final thought on the "slippery slope": usually mountains do not come with only one slope. On the other side of the mountain, there is another descent. By not extending the parens patriae jurisdiction to yet-to-be-born children whose mothers are substance abusers, we are consigning those children, particularly aboriginal children in an alarming number of cases, to a life filled, not with promise and potential, but with disease and disabilities, crime and conflict. And we are virtually ensuring that the next generation will be the same. The role of the Court should be to balance rights and interests so that each child remains safely protected at the mountain's top.

\section{Judicial Extension of the Common law}

The majority, however, did not want to extend the parens patriae jurisdiction over minors to provide legal protection of the unborn child from substance abuse during pregnancy because of the general principle that the courts will not extend the common

D.F.G., supra note 1 at 238 (S.C.C.) [emphasis in original]. Justice Major declared that "[i]t will only be in extreme cases, where the conduct of the mother has a reasonable probability of causing serious irreparable harm to the unborn child, that a court should assume jurisdiction to intervene" [emphasis in original].

Ibid. at 239.

Ibid.

Ibid. at 228.

lbid. at 239.

Ibid.

lbid. at $\mathbf{2 4 0 .}$

lbid.

Ibid. 
law "where the revision is major and its ramifications complex..." The Supreme Court of Canada decision in Watkins ${ }^{60}$ was quoted as the precedent for this general proposition. Ironically, the principle actually declared in that decision, and quoted by the majority, was that "where the revision is major and its ramifications complex, the courts must proceed with great caution." ${ }^{1}$ It could be argued that it was the minority who actually applied the rule stated in Watkins and "proceeded with great caution" in its decision to extend the parens patriae jurisdiction.

The majority's decision to alter, arguably, the previously articulated principle and declare that the Courts will not extend the common law where "the revision is major and the ramifications complex" is consistent with its position that the legislature, and not the courts, should address the issue of legal protection for the unborn child. Similarly, the minority's reliance on the original principle that the courts must "proceed with great caution" is consistent with its view that legislative inaction is not an excuse for the judiciary to follow the same course of inaction. In the author's view, the minority appropriately applied Watkin's principle, proceeded with great caution, and properly extended the common law.

The minority decision was developed on the fundamental concept that the muchadmired flexibility of the common law was required for the purposes of this case. ${ }^{62}$ It therefore developed the minimum threshold that would have to be met to justify state intervention. In so doing, Justice Major emphasized that "the threshold for state intervention is high" 63 because the mother's liberty is at stake and "each case will have to be decided on its facts." ${ }^{24}$ The minority's conclusion, summarizing why the minimum threshold had been met, exemplified the value of allowing the Court to "proceed with great caution" even when the changes to the common law are major:

When confinement is determined to be the only solution that will work in the circumstances, this type of imposition on the mother is fairly modest when balanced against the devastating harm substance abuse will potentially inflict on her child. The afflicted children may be sentenced to a permanently lower standard of life. To advocate not confining the mother to prevent this harm seems extreme and shortsighted."s

It may be argued that the minimum threshold described in the minority decision is too vague to properly address the complex issues related to judicial extension of the parens patriae jurisdiction. Justice Major emphasized that each case has to be decided on the facts. This is, precisely, how the common law is developed - over a series of cases, each of which provides nuances to the common law based upon its specific facts. It should be noted that a Court-developed extension of the parens patriae jurisdiction

Ibid. at 204.

Watkins v. Olafson, [1989] 2 S.C.R. 750 [hereinafter Watkins].

Ibid. at 760-61 [emphasis added].

D.F.G., supra note 1 at $219-20$ (S.C.C.).

Ibid. at 240.

Ibid.

Ibid. at 241. 
does not preclude legislative intervention. On the contrary, Justice Major implied that legislative intervention would be preferable. ${ }^{66}$

A significant shortcoming of the majority judgment was that it failed to recognize the fundamental differences between tort law which focuses on a breach of a duty of care, and the parens patriae jurisdiction which "exists for the stated purpose of doing what is necessary to protect the interest of those who are unable to protect themselves."67 Rather, the majority declared that it rejected "extension of the court's parens patriae jurisdiction to permit protection of unborn children ... for reasons similar to those enunciated in connection with the submission that the law of tort should be extended to the unborn." ${ }^{\text {"68 }}$ Whereas it is arguably appropriate to extend the parens patriae jurisdiction to assist both the mother and unborn child who are unable to help themselves because of the mother's bondage to addicting substances, it is not appropriate to make an addicted pregnant woman liable for breach of a duty of care to her unborn child resulting from a pattern of behaviour over which she has no control.

The majority's decision not to judicially extend tort law to provide legal protection for the unborn child from substance abuse during pregnancy may be supportable. However, to reason that it is not appropriate to extend a duty of care to an addicted pregnant woman does not mean that an alternative pre-birth remedy should be rejected. In fact, there would be a grotesque contradiction in our legal system to permit an unborn child to sue for damages sustained as a "non-person" but not provide a legal mechanism to prevent that damage from occurring. In the words of Justice Major:

It seems fundamentally unfair and inexplicable for this Court to hold that a foetus, upon live birth, can sue for damages to recompense injuries suffered in utero, yet have no ability to obtain a remedy preventing that damage from occurring in the first place. This is one of the clearest of cases where monetary damages are a singularly insufficient remedy. If our society is to protect the health and wellbeing of children, there must exist jurisdiction to order a pre-birth remedy preventing a mother from causing serious harm to her foetus. ${ }^{69}$

The common law must maintain its flexibility so that it may respond to the facts of each case. The original general principle that the courts must proceed with great caution when an extension of the common law involves major changes with complex ramifications must be followed. It is essential that the courts be able to call upon the

Ibid. at 242. There is no logical reason why, even if legislation did exist, an extension of parens patriae jurisdiction could not co-exist with it. For example, what position should the court take if 7 or $\mathbf{8}$ provinces legislated to protect unborn children but 2 or 3 did not? In such a situation we would argue that the parens patriae jurisdiction would still be necessary. lbid. at 232.

as Ibid. at 214-15. The minority emphasized that:

...extension of the parens patriae doctrine in the case on appeal should not be viewed as an implicit sanctioning of a child's right to sue its mother for 'lifestyle choices' made during pregnancy. A child initiating any action against its mother would have to prove, in this type of action as in others, all the elements of a negligence claim, including causation and damages to the standard required in all tortious actions (ibid. at 239). 
adaptability of the common law. As Justice Major observed: "Where the harm is so great and the temporary remedy so slight, the law is compelled to act.""

\section{ARe You having a Dialogue if the Other Party ISN't Listening?}

In the wake of D.F.G., we see that, once again, the question of legal protection for the unborn child has been left to the legislatures. The Morgentaler" case has been described as "an act of judicial statesmanship" 72 that should have "forced Canadian lawmakers to deal with the abortion issue." no resolution of the matter and the controversy continues. The majority decision in D.F.G. may be viewed as a similar, albeit more direct and aggressive, act of judicial statesmanship. There is really little more that the Supreme Court of Canada could have said in this decision to urge the legislatures to address the issue of legal protection for the unborn.

Justice McLachlin's judgment on behalf of the majority is radical in that it repeated almost twenty times, in an otherwise concise judgment, that an order for the detention of pregnant woman for the purpose of preventing harm to her unborn child requires changes to the law which are "best left to the wisdom of the elected legislature." ${ }^{74}$ The fact that the Court was compelled to repeat itself, even to the point of condescension, raises the question as to why the Court deemed it necessary to constantly restate that the legislatures, and not the Courts, are responsible for law reform concerning legal protection of the unborn child. The most likely reason for this repetition is the legislative inaction subsequent to Morgentaler. ${ }^{75}$

Glendon commented that in striking down the Criminal Code regulation of abortion, the Supreme Court of Canada in Morgentaler "scrupulously rested its holding on narrow grounds, leaving the legislature with wide latitude to fashion a new system of abortion regulation." Glendon agreed with the comment that the decision was "a provisional ruling, a ruling that invited Parliament to reconsider the question of abortion, perhaps with a more informed and thoughtful understanding of the relevant competing interests."

A decade later, Canadian legislators have not enacted a new abortion statute nor have they made any progress whatsoever toward that end. The result being, as noted by

70

7

M.A. Glendon, Rights Talk: The Impoverishment of Political Discourse (New York: The Free

Press, 1991) 165 [hereinafter Rights Talk].

$n \quad$ D.O. Conkle, "Canada's Roe: The Canadian Abortion Decision and its Implications for American

Constitutional Law and Theory" (1989) 6 Constitutional Commentary 299 at 311.

D.F.G., supra note 1 at 242 (S.C.C.).

R. v. Morgentaler, [1988] 1 S.C.R. 30 [hereinafter Morgentaler].

F.L. Morton, "The Meaning of Morgentaler: A Political Analysis," in I. Gentles et al., A Time To Choose Life (Toronto: Stoddart Publishing Company, 1990) 168 at 184.

Ibid.

D.F.G., supra note 1 at 219 , para. 56 (S.C.C.). Further references to Justice McLachlin's repetition of the need for legislation are found at paras. 4, 7, $12(x 2), 18,20,24,26,29,45,46(x 2), 47,53$ (x2).

Morgentaler, supra note 71 at 46 
Professor Morton, the present "non-policy" approach to abortion has left Canada "as the only Western democracy not to provide at least symbolic support for the unborn child while still respecting a woman's freedom to choose." 78

The Morgentaler decision is considered by abortion rights activists to be an absolute victory. However, it was not the Court's decision that made the victory absolute. Parliament's inaction made it so. The decision was written in such a way as "to leave maximum leeway for legislative decision-making."79 Furthermore, Chief Justice Dickson emphasized that "courts are not the appropriate forum for articulating complex and controversial programmes of public policy." ${ }^{80}$ It is little wonder the Supreme Court of Canada went to such great extremes to delineate the appropriate roles of the courts and the legislatures regarding complex social issues.

Further, in Tremblay v. Daigle, ${ }^{81}$ the Supreme Court held that "a fetus is treated as a person only where it is necessary to do so in order to protect its interests after it is born." ${ }^{82}$ The misconceptions regarding the Morgentaler and Daigle decisions, including the idea that the unborn child is entitled to neither common law nor legislative protection, may explain why the majority in D.F.G. deemed it necessary to highlight the fact that, although the common law does not recognize the unborn child as a legal or juridical person, the legislatures may legislate legal protection for the unborn child. "If Parliament or the legislatures wish to legislate legal rights for unborn children or other protective measures, that is open to them, subject to limitations imposed by the Constitution of Canada." ${ }^{83}$

Although the majority's unprecedented "demand" for legislative intervention was commendable, and although legislative intervention is preferable, "its failure to do so is not an excuse for the judiciary to follow the same course of inaction." ${ }^{84}$ While it is indisputable that initiatives to prevent substance abuse during pregnancy must be primarily directed at "counselling, rehabilitation, outreach and support services designed specifically to meet the needs of pregnant women with alcohol addictions," ${ }^{85}$ judicial intervention in rare and extreme cases must be available to the state for it to enforce

F.L. Morton, Morgentaler v. Borowski: Abortion, the Charter and the Courts. (Toronto: McClelland and Stewart, 1992) at 313 (hereinafter Morton]. Because the Supreme Court's ruling has been distorted and manipulated by the raging "pro-life" versus "pro-choice" debate, it is no wonder that the majority in D.F.G. was determined to make it perfectly clear that the decision was neither a denial of fetal rights nor an affirmation of women's right to absolute freedom of choice. Rights Talk, supra note 76 at 163.

Morgentaler, supra note 71 at 46.

[1989] 2 S.C.R. 530.

Ibid. at 563, cited in D.F.G., supra note 1 at 237 (S.C.C.). The minority commented in this regard that "[p]rotecting the unborn child from having to live its life suffering from severe mental and physical disabilities should meet the test of necessity to "protect its interests after it is born."' D.F.G., supra note 1 at 202 (S.C.C.).

Ibid. at 242.

*s Report, supra note 42 at 965 (recommendation 275(c)). 
its "interest in ensuring, to the extent practicable, the well-being of the unborn child." 86

In Vriend, ${ }^{87}$ Justice Iacobucci described the interaction between the Court and the legislatures as one of "dialogue." 88 By this he meant that the Court, during the process of judicial review of legislation or executive action, will "speak" to the legislatures as to the appropriate course of action for the legislatures to undertake. The legislature will then respond with revised legislation or a different approach to executive action that the Court most likely will find acceptable. If the legislature does not wish to follow the course of action suggested by the Court, they can always invoke the "Notwithstanding Clause."

It appears, however, that in regard to the interests of the unborn, the legislatures are not listening. In Morgentaler, the Supreme Court spoke, but apparently Parliament was not listening. In Daigle, the Court spoke but once again the legislatures were not listening. In this realm - the interests of the unborn - it appears that the "dialogue" has failed. Whether because of the tyranny of ideology or the paralysis of politics, the "dialogue" has broken down. Now, in D.F.G., the Court has spoken again, in the most forceful manner possible. The question remains: are the legislatures finally listening? ${ }^{89}$

\section{CONClusion}

We noted earlier that Canadians do not generally adhere to absolutist positions. We are essentially balancers. The position of the unborn child in Jewish Law provides an interesting example of balancing. If the life or health of the mother - either physical

D.F.G., supra note 1 at 220 (S.C.C.). Indeed, two American States have adopted legislation directed at the prevention of prenatal substance abuse. Effective July 1, 1998, South Dakota becomes the first state which provides for the involuntary commitment for alcohol and drug treatment of pregnant substance-abusing women. S.D. Codified Laws \$34-20A-63 \& 34-20A-70 (Michie: 1996 \& Supp. 1998). This legislation follows comprehensive legislation passed in Minnesota in 1989 and 1990 enacted to facilitate early identification of, and voluntary treatment services to, drug abusing (excluding alcohol) pregnant women (Minn. Stats. Ann. \$626.5561 (West 1996)). For a discussion of "Minnesota's Answer," please refer to M. Lencewicz, "Don't Crack the Cradle: Minnesota's Effective Solution For The Prevention of Prenatal Abuse - Analysis of Minnesota Statute Section 626.5561" 63 Rev. Jur. U.P.P. 599. Civil commitment under the Minnesota scheme is sought only if the woman rejects the recommended services or fails treatment. Minn. Stats. Ann. $\$ 235$ b.02 (West 1982 \& Supp. 1991). Vriend v. Alberia (1998), 156 D.L.R. (4th) 358.

kn Ibid. at 439, citing P.W. Hogg \& A.A. Bushell, "The Charter Dialogue Between Courts and Legislatures" (1997) 35 Osgoode Hall L.J. 75 at 82.

89 Both Justice Twaddle of the Manitoba Court of Appeal (D.F.G., supra note I at 262 (Man. C.A.)) and Justice Major of the Supreme Court (D.F.G., supra note 1 at 238 (S.C.C.)) noted that through its national government, Canadian society has already recognized a need to offer legal protection to an unborn child in the preamble to the Declaration of the Rights of the Child (adopted by the United Nations in 1959 with Canada as a signatory):

"...the child, by reason of his physical and mental immaturity, needs special safeguards and care, including legal protection, before as well as after birth..."

(U.N. Document A/4354 (1959): see also Convention on Rights of the Child, U.N. Document A/RES/44/25, concluded November 20, 1989, entry into force September 1, 1990; in force in Canada December 13, 1991). 
or psychological - is in danger, the mother takes precedence over her unborn child for the unborn child does not have the status of a person in Jewish Law. ${ }^{90}$ Thus, abortions for the purpose of safeguarding the life and health, physical or psychological, of the mother is permissible in Jewish Law." Otherwise, however, the potential future life of the unborn child is worthy of protection. For example, one may desecrate the Sabbath to save an unborn child even if there is only a possible danger or even if the life saving measures may prove fruitless. ${ }^{92}$

Jewish Law places an emphasis on obligations as opposed to rights. It is the obligation of the mother (and the father) to safeguard the unborn child. Thus, lifestyle preferences which harm the unborn child would be a violation of the obligation to safeguard the fetus. It is also the obligation of others to ensure that the obligations of the mother and the father towards the unborn child are fulfilled. ${ }^{93}$

Based upon this analysis, and given the precedent of the Morgentaler case, we might suggest that once the mother has decided, by action or inaction, to bring the unborn child to term and not to have an abortion, an obligation arises on her to keep the child safe from harm. If, in extreme cases, due to the severe addiction of the mother, it is likely that the unborn child will suffer serious and irreparable injury and no other measures exist for dealing with the problem, then the state may intervene to confine the mother and ensure that she is treated for her substance abuse so as to prevent future harm to the child which will manifest itself once born.

This is essentially the position taken by Justices Major and Sopinka in dissent.

Cover notes that "law is a bridge in normative space." "It connects the world we live in and the world we wish to create. In this he is echoing the ancient commandment to "mend or perfect the world." 95 Here, the dissent is attempting, admittedly in a small way, to mend the world through law.

Of course, the majority is correct in law. What a shame!

Mishnah Ohalot 7:6.

Ibid:; Choshen Mishpat 425:2.

O.H.300:1; Shab.128b; Shab.132a; b.Yoma 85a; M.Yom.8:6.

Sha.128-129a; Nefesh1:16. There are also references in the Torah regarding life and property: Duet. 22:8; Duet. 4:9. The complete discussion on the Jewish Law of abortion and personhood is, of course, more complicated than the foregoing.

R.M. Cover, "Bringing the Messiah Through the Law: A Case Study," in NOMOS XXX: Religion. Morality and the Law, R. Pennock \& J. Chapman, eds., (New York: New York University Press, 1988) at 201.

This quote is based on a reference in the Kaballah of Olam Hatikkun, referring to to "a world of the improved" from Isaac Luria. The quote also refers to the concept of Tikkun Olam or "to repair a broken world." It is the obligation of mankind to work in harmony with God and mend the world's ills so that it is perfected as God intended it to be. 